\title{
AN OUTBREAK OF THE RED-STRIPED SUGAR-CANE SCALE
}

By H. L. Dozier, Chief Entomologist, Insular Experiment Station

One of the most interesting occurrences of the past year was the serious outbreak of a scale insect on sugar cane near Arecibo, something heretofore unknown to have occurred on the Island. This scale, upon study, was found to be Pulvinaria iceryi Guérin, a species of which six individuals were reported on leaves of sugar cane at Cayey and Trujillo Alto. It was also reported by Smyth as being abundant in 1919 on his cane grown in the greenhouse where possibly it was protected from its natural enemies. Smyth also reported an apparent 6.6 per cent success in transmitting mosaic with this insect, but his experiments need repeating under better control conditions for substantiation. In addition to Porto Rico, the species has been recorded from British Guiana, Mauritius, and the Reunion Islands. The U. S. Bureau of Entomology has received specimens of this species from the southern part of Georgia (U. S. A.) on sugar cane on several oceasions.

It seems rather surprising that this species, after being so long present on the Island, should now suddenly show up in epidemic form. The only theory the writer can advance is that the species which has heretofore been held in check by its parasites was at last. eaabled to gain the upper hand by a sudden upset in the "balance of nature". This theory is upheld by a study of the intermal hymenopterous parasites attacking this species during the outbreak.

THE RED-STRIPED SUGAR-CANE SCALE

(Pulvinaria iceryi Guérin = elongata Newstead.)

On May 27th, 1925, a trip was made by the writer to Arecibo to investigate a reported oubreak of a seale insect attacking sugar cane. It was found that an unfamiliar scale had attacked a block of forty-five cuerdas of young Rayada cane on the farm of Sr. Juan Santos, a colono of the Central Cambalache, about six kilometers from Arecibo on the main highway towards Mayagüez. This insect had been first noticed by Señor José Oliver the latter part of April in a piece of first-ratoon cane, three months after cutting. At that time an average of about one hundred female scales were found to the stool over an area of about five cuerdas. This cane had been cut 


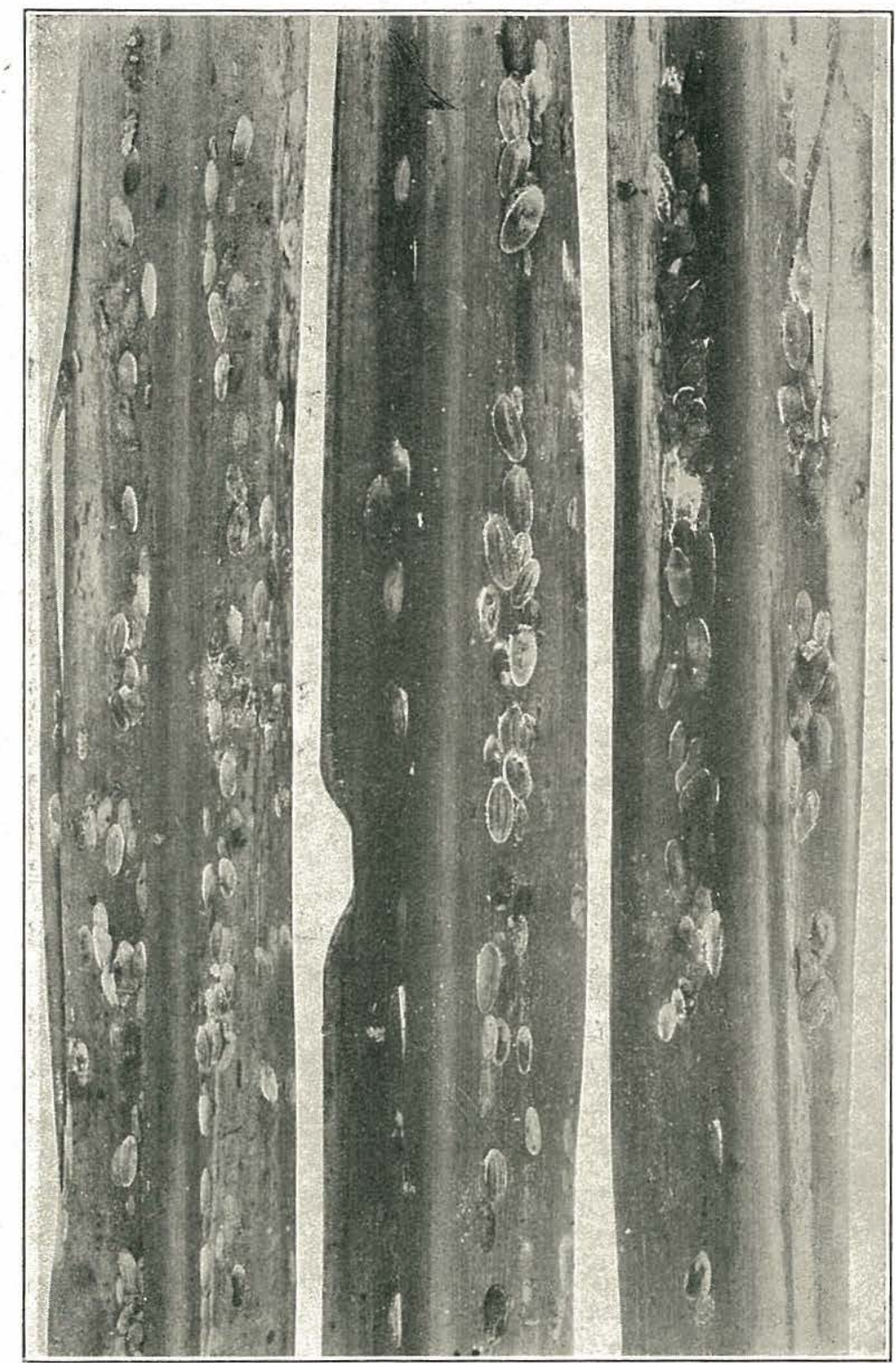

FIG. 1.-The Red-striped Sugar-cane scale Pulvinaria iceryi Guérin= clongata, Newstand, on sugar-cane leaves. About natural size. (Dozier) 
the first of February and was attacked as it ratooned. The cut cane from this field had yielded better than thirty-five tons per cuerda average over the forty-five cuerdas. By the 7th of April the insect was found over the entire forty-five cuerdas. This entire field was then sprayed by the owner, using the old kerosene oil emulsion formula, one part of the stock to ten of water, and applied with a hand sprayer, about thirty stock gallons being used on this application. The cane foliage was not burned and apparently the application gave some good results.

On the day that the Entomologist inspected this field it appeared distinctly yellow in comparison with the other fields adjacent and in certain areas a large number of the older leaves were dead and dying and fairly well infested with the adult mother seales, beneath which were found large numbers of eggs and numerous newly hatched young. The young larvae were very abundant, settling on the new foliage, and giving promise of more serious damage later. For the three months previous to this time no rain had fallen in that section and this sudden outbreak might have been connected in some way with this extremely dry period.

Again, on June 26th, the writer made a survey of conditions and found that the insect was continuing its damage and in about as abundant numbers as before. At this time the adult females of what was probably the third generation were very abundant and newly hatched crawlers were infesting the new foliage. A strip of about four cuerdas of this field was almost a complete loss and active spray measures were being taken against the remainder.

\section{DESCRIPTION AND JIEE HISTORY}

The full-grown female scale is very much elongated, measuring $6.50 \mathrm{~mm}$. in length and $2.50 \mathrm{~mm}$. at its greatest width, and although rather flat as a whole is distinctly raised or convex with the surface entirely smooth. It is of a testaceous-yellow color with two rather narrow but well-separated, distinct reddish stripes running almost parallel for most of the body length. These two stripes make their appearance early in the life of the seale, being more or less distinct in the second instar larva and becoming more conspicuous and prominent as the scale matures. These two reddish stripes serve as a ready means of identification and distinguish it from all of the other scales known in Porto Rico. At times the sides of the fullgrown scale have a more or less diffusion of reddish vein-like markings outward from the two median longitudinal stripes. After young 
are produced these two reddish lines break up into rather faint irregular brownish markings, leaving the scale covering for the most part a testaceous-yellow in color.

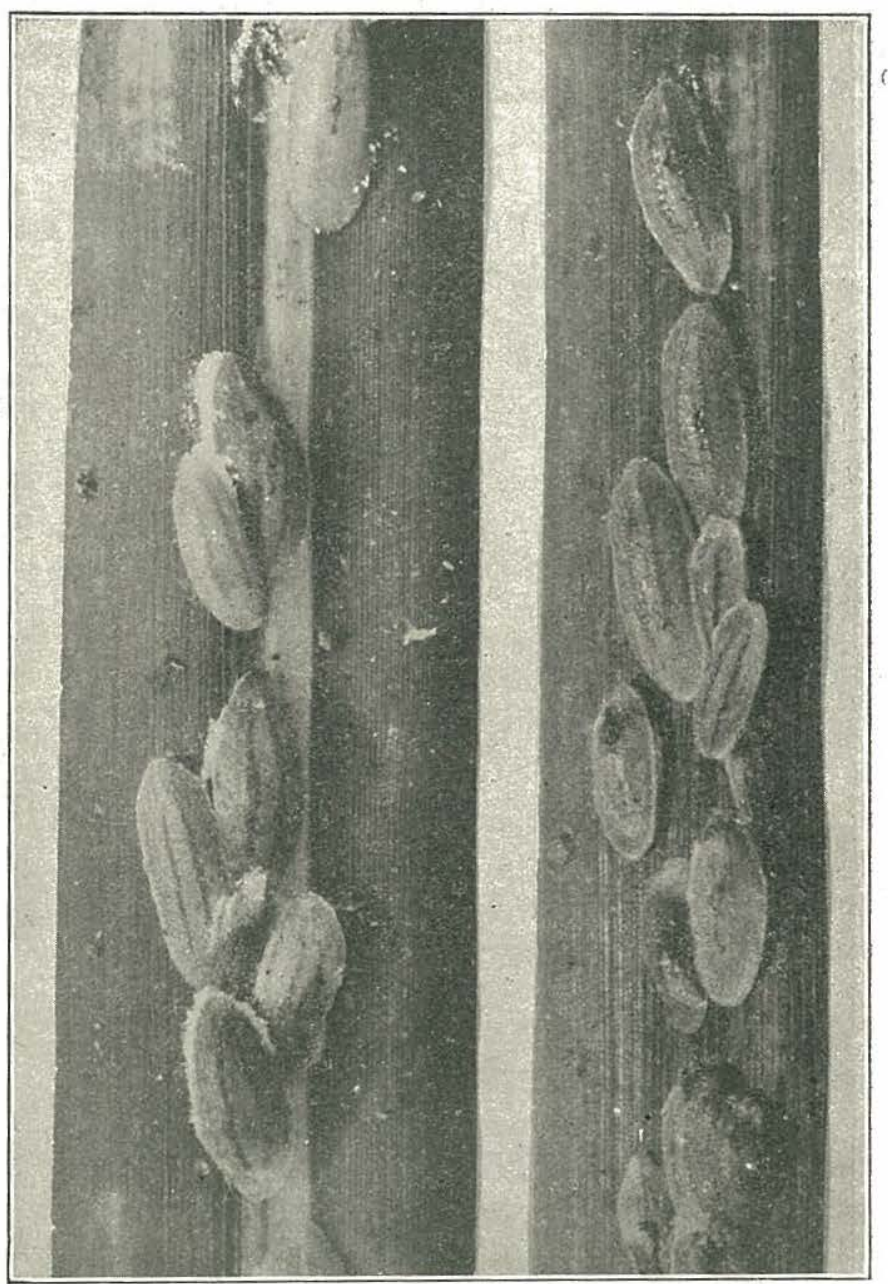

FIG. 2.-The Red-Striped Sugar-cane Scale, Pulvinaria iceryi Guérin = elongata Newstand, on Sugar-cane leaves. About 2 times natural size. (Dozier)

The full-grown and mature female forms a cottony or mealy excretion beneath the scale covering which together with the sugarcane leaf forms an ovisac and serves as a protection in which the eggs are deposited and where the young are protected after hatching 
until they issue out from under the mother scale covering. The eggs are elongate-elliptical in shape, about twice as long as wide at the greatest width, measuring $0.416 \mathrm{~mm}$. in length by $0.224 \mathrm{~mm}$. width, and are of a pale dirty white color. Over one hundred eggs were counted beneath one scale.

The male scale of this species is still unknown although a careful search has been made and much material put up in emergence boxes. In fact it seems that this species must reproduce itself parthenogenetically, that is, without the necessity of being first fertilized by the male.

The newly hatched larva or "crawler" is a testaceous-yellow in color, elongate-oval in outline, measuring $0.528 \mathrm{~mm}$. in length by $0.208 \mathrm{~mm}$. width, with a pair of antennæ or feeler and a pair of long filaments projecting from its hind end. The feet are well developed and the larvæ of most of the stages are very active and frequently change their feeding position on the leaf. In the last instar, however, the full-grown scale is stationary. The newly hatched crawlers react very positively to light and their favorite settling place is along the leaf in the lengthwise depressions and in most cases on the underside of the leaves. Very rarely do they settle and feed along the stalk of the plant.

\section{NATURAL ENEMIES}

Adults and young of the ladybird beetle, Cryptolaemus montrouzieri, were abundant over the field feeding on the scales of various sizes and many were noticed feeding beneath the adult female scales where they had pushed them up off of the leaf. This beetle was imported from California into Porto Rico by Van Dine in 1911, bred in numbers and turned loose at various points on the Island, and is now after many years proving itself a very beneficial insect, attacking many species of scale insects here.

Material of this scale was placed in parasite-rearing boxes at the time of the first investigation with the result that three species of hymenopterous parasites were reared, a primary parasite, Aploycus flavus How; a secondary parasite upon this species, evidently Cheiloneurus pulvinarice Dozier; and a few spesimens of a coccophagine, Aneristus ceroplastce How. Later, from more material collected in July the most abundant parasite reared was Aneristus ceroplastce and it was proved by dissecting the adult female scales that this was a primary parasite. In examining parasitized scales some were found with as high as seven and eight emergence holes in them. Out of 
275 scales examined on July 10th, 71 were found parasitized, or only 28.7 per cent. With the first batch of material the Cheiloneurus was far more abundant than either of the primary parasites, a fact that probably accounts for the rapid rise and spread of the scale without effective natural control.

The following descriptions and drawings are given to enable ready identification of the species of parasites concerned.

\section{Aphycus (Euaphycus) flavus How.}

The writer is indebted to Mr. P. H. Timberlake who, in making the identification of this species, states that although the type of flavus has apparently been lost, these specimens agree with what has gone in literature in past years as typical flawus.

Female: The frontovertex is about twice as long as wide; the ocelli placed in an acute-angled triangle, the posterior pair clo'se to the margin of the eyes. Antennae inserted near the mouth. Antennal scape flattened and narrow, four times as long as wide at greatest width near the middle, pedicel as long as the first three funicle joints combined; first four funicle joint subequal in length and breadth, the fifth slightly longer and the sixth distinctly longer; fifth and sixth increasing in width so that the sixth is nearly twice as wide as the first joint; club three-jointed, a little wider than the last funicle joint and nearly as long as the last five funicle joints combined. Forewings typical with the oblique hairless streak widened and interrupted below. Hind wings short, the marginal hairs relatively long. Abdomen shorter than the thorax and of about the same width.

General color of upper surface of body an orange yellow, the legs and underpart a paler yellow. Pronotum pale yellow with a fuscous dot on each corner. Antennae yellow, a longi tudinal streak or spot on the upper margin of outer surface of the scape towards its apex, the base of pedicel, the first three funicle joints, and the basal half of club, fuscous; the club a yellowish-white in apical half. Legs a uniform pale yellowish, the tarsal claws blackish. Wings hyaline with the veins yellowish.

Length, exclusive of ovipositor, $0.70-1.20 \mathrm{~mm}$.

Male: Similar in coloration to the female except that the metanotum, propodeum and dorsum of abdomen, especially towards apex, are embrowned. Antennae also similar in structure except that the joints all increase in width successively, the club is not three-jointed as in female; the entire flagellum is uniformly dusky.

Length, $0.640-0.840 \mathrm{~mm}$.

Reared in abundant numbers as a primary parasite from Pulvi- 
naria iceryi on sugar cane at Arecibo, P. R., during May and July, 1925. Aphycus flavus has been recorded by various workers as being reared from Toumayella liriodendri, Tachardia sp., Pulvinaria pyriformis, Coccus hesperidum, Chrysomphalus dictyospermi, Aspidiotus hederae, and Saissetia oleae.

\section{Cheiloneurus pulvinariae n. sp.}

In the female sex this species resembles most closely $C$. inimicus Compere, but is distinguished by its distinctly smaller size, its lack cf a black line on the ventral margin of scape, by having no metallic color on propodeum, and difference in wing venation. The male is
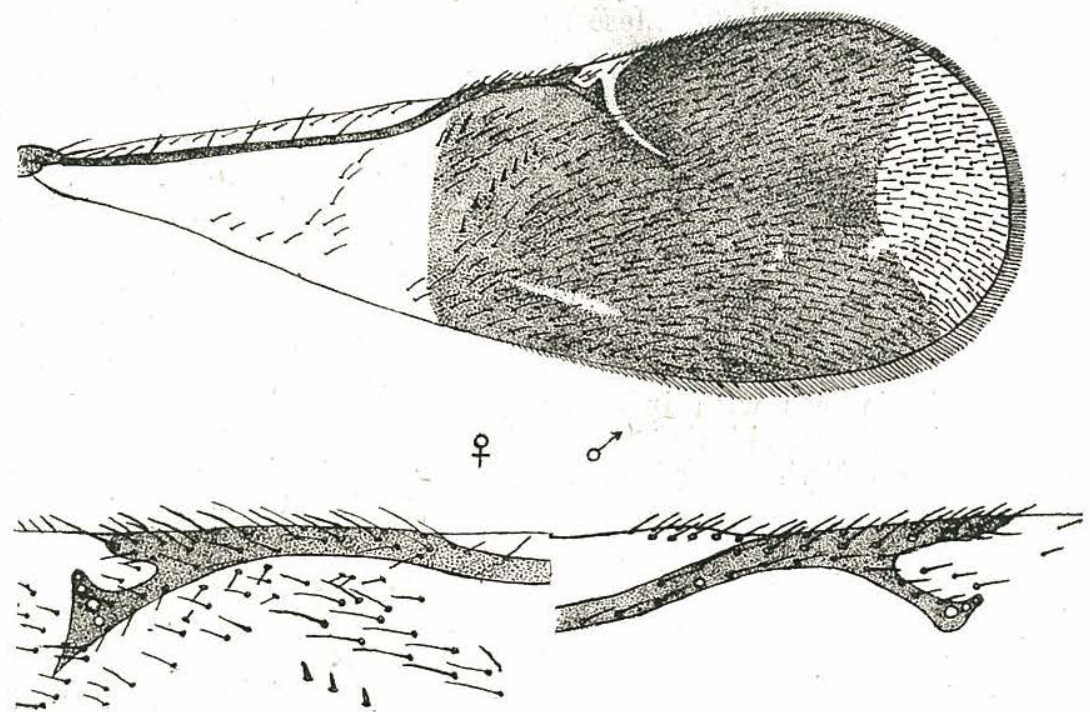

FIG. 3.-Cheiloneurus pulvinariae n. sp. Above, wing of female. Below, venation of forewing of male and female, much enlarged. (Dozier)

nore easily distinguished by having the eyes hairy, and the first funicle joint much longer and with more hair.

Female: Head about one and one-half times wider than long; ocelli arranged in an acutely-angled triangle. Antennal scape slightly expanded below, nearly three times as long as widest width; pedicel triangular, as long as the first two funicle joints combined; funicle joints gradually widen so that the sixth is almost twice as wide as the first; first four joints of funicle about equal in length, the sixth a fourth longer than the fifth. Club three-jointed, oblongate, slightly wider than the scape and about the same length. Mesothoracic scutum about twice as wide as long. Scutellum only slightly wider 
than long with the characteristic tuft of black bristles. Pronotum and mesoscutum very finely reticulated, with numerous setigerous punctures, the punctures of the silvered area being larger and elongate; mesoscutum set with eight strong blackish hairs on hind margin; the scutellum is more distinctly and coarsely reticulated. Abdomen about same length as the thorax, with ovipositor sheath slightly exserted. Wing with characteristic embrowning and venation as in Fig. 5.

General color yellowish-orange. Eyes dark. Antennal scape soiled yellowish with the margins slightly embrowned; the pedicel and first three funicle joints more or less distinctly fuscous, varying greatly in slide-mounted material; hairs of the first three joints darker and more prominent than those of the other funicle joints; fourth, fifth and sixth joints a testaceous-yellow. Mesoscutum testaceous yellow with two more or less distinct longitudinal, more orange-colored stripes passing through its length onto the scutellum, in slide-mounted specimens. The posterior third is crossed by a broad dark band that is overlain with an iridescent silvery sheen. Scutellum, metanotum, and propodeum yellowish with slightly darker color than the mesoscutum. Abdomen dirty yellowish with the basal segments and the apex of the last segment embrowned. Femora and tibiæ testaceous-yellow, with varying degree of fuscous markings, forelegs with only slight infuscation along the dorsal margin of femora towards apex; middle legs with infuscation dorsally near knee; hind legs with dorsal sides of femora infuscated, the tibiæ with a more or less distinct band across width on upper third and a blotch on disc of lower third, fuscous; all tarsi testaceous, the claws dusky.

Length, exclusive of ovipositor, $1-1.10 \mathrm{~mm}$.

Male: Antenae entirely different from those of female: scape long and slender, the pedicel very short, much shorter than the first funicle joint; funicle joints each distinctly narrowed towards distal end and furnished with partial whorls of long, diverging hairs as in illustration. The hairs on scutellum are not in a tuft as in female sex. Pronotum, mesoscutum, axillæ, and scutellum distinctly reticulated.

General color a dark brown, the legs lighter in part. Antennae with scape pale, the margin's slightly embrowned the pedicel distinctly dark, and the flagellum uniformly light brown. Wings hyaline without markings.

Length, 1-1.08 $\mathrm{mm}$.

Described from a series of balsam-mounted specimens, twelve females and two males May 28-31, 1925, one female and one male June 6, 1925, and two females and three males July 10, 1925; all reared by the writer from Pulvinaria iceryi during severe outbreak of this scale on sugar cane at Arecibo. It seems certain that this 
is a hyperparasite on the primary parasite of this scale, Aphycus flavus, with which it was always reared.

Types deposited in U. S. National Museum; paratype material in collections of the writer, P. H. Timberlake, and the Porto Rican Insular Experiment Station.

The adult of the following parasite is very active and carries its abdomen at an elevated angle, a mannerism which is very characteristic of this species.

\section{Aneristus ceroplaste How.}

This species, the only American representative of the genus, was first described in 1895 from two female specimens reared by T. D.

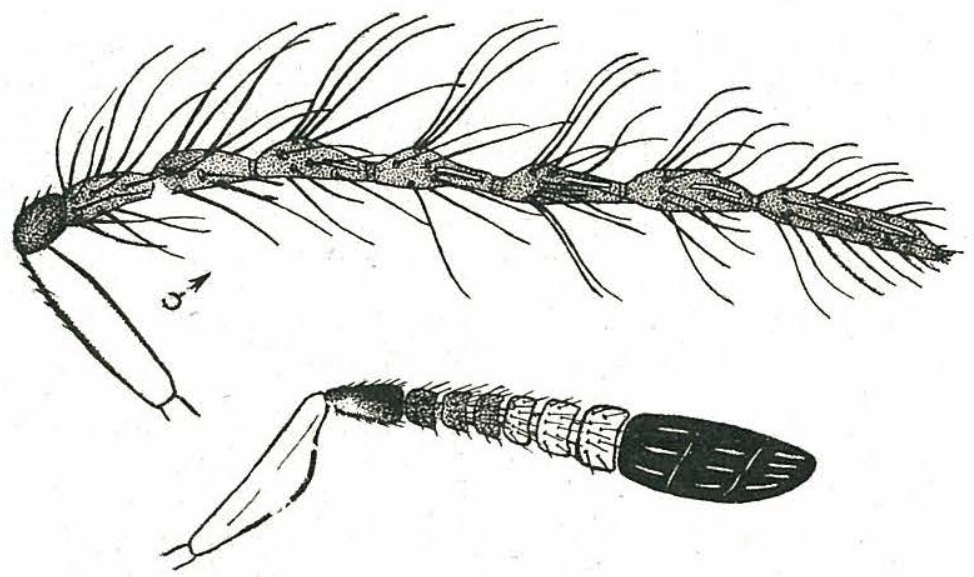

FIG. 4.-Cheiloneurus pulvinaria n. sp. Above, antenna of male. Below, antenna of female. Much enlarged. (Dozier)

A. Cockerell from Ceroplastes sp. on Euphorbia loypericifolia from Jamaica. Again in the same year Dr. Howard described Coccophagus orientalis from thirteen females reared by E. E. Green at Pundulaya, Ceylon, from Ceroplastes actiniformis, Lecanium viridis, Lecanium coffece, and Dactylopius adonidum, with the statement that it "seems to be an abundant and general scale insect parasite in Ceylon". According to Timberlake Coccophagus orientalis is a synonym of Aneristus ceroplastce, and the species is widely distributed in the Tropies, occurring in Hawaii, Philippines, Java, India, and the West Indies. A female of this species was reared by the writer in New Orleans, La., from Coccus hesperidum material on citrus, January 15, 1925. The male has not yet been described and the writer deems it best to give here a full description of both sexes. 
Female: Resembles greatly a Coccophagus, being distinguished from members of that genus only by the shape and structure of the posterior tibiae. Head slightly wider than long. Eyes rather large, with scattered microscopic hairs. Ocelli placed in an equilateral triangle. Lateral and hind margins of vertex with prominent black bristles, the dorsal surface with smaller black bristles scattered over the surface. Upper surface of vertex somewhat coarse, the cells being pentagonal or quadrate, but with each hind corner at eyes the pattern becomes longer and more transversely drawn out. Serobes deep and about as wide and long at the antennal scape. Antennae with scape about equal in length to the pedicel and first two funicle joints, inserted just above the mouth and reaching to middle of the face, somewhat flattened from the side, under high power large and coarsely reticulated; pedicel short, triangular, slightly longer than wide, distinctly and coarsely reticulated. The entire flagellum very much flattened with the longitudinal elevations very strong and numerous. First funicle joint twice as long as pedicel, somewhat longer than broad, slightly longer than the second; the second and third funicle joints each successively shorter but of about the same width; joints of funicle supplied with numerous stout bristles. Club distinctly three jointed, with the first joint a little broader than the funicle joints, the second and third successively diminishing in width, all joints subequal in length, the last tapering to a blunt point. Thorax shagreened and rather densely set with stout black bristles, under high power with distinct and coarse reticulated pattern on dorsum with exception of the propodeum. Forewings nearly two and a half times as long as broad, the surface set with bristles which are much stronger and more prominent on the clouded area; marginal vein very long and straight, the stigma very short. Legs with the hind femora very large and flattened, the hind tibiae also much flattened with a distinct row of short stiff bristles along outer margin; middle tibial spur about as long as the first tarsal joint, which is decidedly longer than the first two tarsal joints combined.

General color is black with slight purplish reflections. Antennae dark brown with exception of the light colored scape. Wings hyaline, the forewings with a large discal fuscous blotch that extends completely across width of the wing. Legs blackish-brown, the tarsi and tibiae of front legs whitish; posterior half of middle tibiae also whitish.

Length, exclusive of ovipositor, $0.940-1.20 \mathrm{~mm}$.

The male differs from the female in having the forewings entirely hyaline and the antenae pale in color; otherwise about the same as female in structure and coloration.

Length $0.7-.760 \mathrm{~mm}$.

The writer has reared this species from Ceroplastes cirripediformis material on Ficus, June 28, 1925, at Santurce; from sam? 
scale on Passion flower vine at Bayamón, July 3, 1925; from Saisettia haemisphaeria on avocado, June 16-18, 1925, at Río Piedras; from Eucalymnatus tessellatus on Calophyllum antillarum, June 21, 1925, at Santurce; and in large numbers from Pulvinaria iceryi on sugar cane at Arecibo. Of twenty-four specimens mounted, only five were males, showing a large preponderance of females, at least during those months. On July 10th many of the black pupae of this species were dissected out, the characteristic antennae making identification easy. They occurred only one to a scale, causing a characteristic blackened area to appear which easily distinguished the parasitized seales from the normal healthy ones. 